\title{
SIMPLIFICATION OF A4 TO AC4 METHOD OF TEST DAY YIELD OF EAST FRIESIAN SHEEP IN MACEDONIA
}

\author{
Nikola Pacinovski ${ }^{1}$, Vladimir Džabirski ${ }^{2}$, Kočo Porču $^{2}$, George Dimov ${ }^{3}$, \\ Goce Cilev ${ }^{4}$, Zvonko Antunović ${ }^{5}$, Goran Trajkovski ${ }^{2}$ \\ ${ }^{1}$ Institute of Animal Science, Ss. Cyril and Methodius" University in Skopje, \\ Blvd. Ilinden 92A, 1000 Skopje, Republic of Macedonia \\ ${ }^{2}$ Faculty of Agricultural Sciences and Food, Ss Cyril and Methodius University in Skopje, \\ Blvd. Aleksandar Makedonski bb, Skopje, Republic of Macedonia \\ ${ }^{3}$ AgroBioInstitute, Blvd. Dragan Tsankov 8, 1164 Sofia, Bulgaria \\ ${ }^{4}$ Veterinary Faculty, St. Kliment Ohridski University, \\ Str. Prilepska bb, Bitola, Republic of Macedonia \\ ${ }^{5}$ Faculty of Agriculture in Osijek, Trg Sv. Trojstva 3, 31000 Osijek, Croatia \\ npacinovski@yahoo.com
}

\begin{abstract}
Individual test day records for East Friesian dairy sheep in Macedonia for 3 year period, taken according A4 method of ICAR, were used for comparison of the two officially approved procedures, e.g. A4 and AC4 with the aim to test the effect of simplification in the milk recording in sheep on the measurement of their individual test day productivity. Data comprised of 1760 records from the Trubarevo breeding flock for ewes of age from the first to seventh lactation. The milking was twice a day and individual yield was recorded in the morning and in the evening of the day of test. Prediction coefficients were developed based on the average morning and evening month/year milk yield in the test day. Predicted daily milk yield based on the morning or on the evening yield was compared to the actual one. Actual, predicted productivity and the differences between the both, were analyzed for the effects of number of lambs born, period of test - suckling ewes and lambs were kept together or milking period ewes and lambs were kept separately, level of production and month of the year. Four way ANOVA was used to analyze the data. Results showed that, in general, AC4 method lead to underestimation of the actual yield (YA) with $0.3 \%$ using morning milking and to $0.3 \%$ overestimation when evening yields were used. Ewes having twins and triplet were underestimated with $1-2 \%$ with the morning milk recording, while in these with singles predicted yield was close to the actual milk yield. The morning recording of the milk yield during the suckling period led to underestimation of the TD yield with about 3\%. The morning prediction of the TD yield in the milking period only is much more accurate. Ewes with high milk production are overestimated with $1 \%$ when the records of morning milk yield were used, while average and ewes with low milk production are underestimated with $1 \%$ and $3 \%$. The prediction of the YA based on the morning milk yield led to about $1 \%$ overestimation in the first part of the lactation, but resulted in about $4 \%$ underestimation during the second part of lactation. The prediction of the YA was equal to the actual yield in the middle of lactation.
\end{abstract}

Key words: A4 method; AC4 method; simplification; East Friesian sheep; milk recording; test day

\section{ПОЕДНОСТАВУВАЊЕ НА МЕТОДОТ А4 ВО МЕТОД АС4 ЗА УТВРДУВАЊЕ ДНЕВНА МЛЕЧНОСТ КАЈ ИСТОЧНО-ФРИЗИСКАТА РАСА ОВЦИ ВО РЕПУБЛИКА МАКЕДОНИЈА}

\footnotetext{
Користени се податоци од индивидуалните дневни записи за принос на млеко кај источно-фризиската раса овци, направени согласно со методот A4 на ICAR во период од три години, заради споредба на двете официјално одобрени методи A4 и AC4, со цел да се утврди ефект од поедноставување на контролата на приносот на млеко кај овците со мерење на нивната дневна индивидуална продуктивност на млеко. Податоците содржеа 1760 записи за стадо овци од с. Трубарево, на возраст од прва до седма лактација. Молзењето се вршеше два пати на ден, со што индивидуалното производство на млеко беше регистирано наутро и навечер. Коефициентите на предвидување беа развиени врз основа на просечното производство на млеко за месец/година, утврдено во текот на контролниот ден. Предвидената дневна количина на млеко, базирана на
} 


\begin{abstract}
утринското или вечерното производство на млеко,беше споредена со фактичката количина. Разликата помеѓу фактичката и предвидената продуктивност беше анализирана во однос на ефектот на бројот на новородени јагниња, периодот на контрола (дојните овци и јагнињата беа чувани заедно, додека за време на молзниот период молзните овци и јагнињата беа одделени), нивото на производство и месецот во годината. За анализа на добиените податоци беше користен четирифакторниот модел ANOVA. Резултатите покажаа дека, во принцип, методот АC4 води кон потценување на реалното производство на млеко за 0,3\% во случај кога се користи утринското производство, а до преценување од 0,3\% кога се користи вечерното производство на млеко. Овците кои имаа близнаци и тројки беа потценувани со 1-2\% со утринското мерење, додека кај оние со едно јагне предвидената количина на млеко беше блиску до вистинската количина. Утринското мерење во текот на дојниот период доведе до потценување на дневното производство на млеко за околу 0,3\%. Утринското предвидување на дневното производство на млеко во текот на молзниот период е многу поточно. Овците со високо производство на млеко се преценуваат за 1\% во случај кога се користи утринското мерење, додека овците со просечно и оние со ниско производство на млеко се потценети за $1 \%$ и $3 \%$. Предвидувањето на вистинската количина врз основа на утринското производство на млеко води до преценување од околу $1 \%$ во првиот дел на лактација, но резултираше со потценување од околу 4\% во текот на вториот дел од лактацијата. Предвидувањето на вистинската количина на млеко беше еднакво со количината на млеко измерена во средината на лактацијата.
\end{abstract}

Клучни зборови: А4 метод; АC4 метод; поедноставување; источно-фризиска овца; млекоконтрола; контролен ден

\section{INTRODUCTION}

Individual control of the milk in sheep is among the most labour cost activities in the farm. The official ICAR recommendations proposed A4 method, including evening and morning measurement of the individual ewe milk production on the monthly bases (ICAR, 2009). The obligatory period is after weaning the lambs, but for better accuracy of the ewe productivity the yield during the suckling period could also be included in the recording scheme.

The technicians usually have difficulties to visit the sheep farms and to record milk yield during lactation every day in the morning and in the evening hours.

The ICAR recommendations assume also alternative procedures for measurement of the individual ewe yield in the day of test (TD) by an approximation by using correction factors and only one individual test for the day, i.e. AC4 (ICAR, 2012). Then the same interval of the test is maintained and the daily yield is predicted on the base of the relative bulk on farm production in the each milking, being two or three times a day. There are no suggestions which of the milkings should be used for individual measurement or at least this is not sufficiently investigated.

Although literature data for simplifying of the A4 method by reducing the number of individual test milkings per day of test are quite limited, it is of interest which time of milking (morning or evening) would be the most suitable for AC4 method implementation in the milking ewe breeding practice. All this with one goal, to get precision results of A4 test day yield with a simpler and less costly method.

Other alternative of the A4 method is A5 which is with longer distance between the individual measurements and AT4 method, which proposes switching between the morning and the evening milkings in every consecutive month of test.

The objective of the study was to compare the accuracy of test day measurement in the sheep of East Friesian breed in Macedonia when it is measured after the official A4 method and with its AC4 simplification.

\section{MATERIAL AND METHODS}

Test day individual milk yield records taken on the monthly base in the morning and in the evening during the whole lactation, e.g. during the suckling and in the milking only period for one flock and for 3 years period were used in the study. The test day was based on two times milking per day. The period was from January to October.

Actual TD (test day) individual milk yield of a ewe (YA) was a sum of her individually measured morning (YM) and evening (YE) yield. The average milk yield of the flock in the morning (AYM) and in the evening (AYE) was used for determination of the correction coefficients. These coefficients are lately used for prediction of the already measured actual individual test day yield based only on the morning (PYM) or on the evening (PYE) milking. The coefficients are calculated separately as relative part of the sum of the actual average flock yields to the average yield during the control part of the day of test: 
- when the test is during the morning milking (CM - coefficient morning):

$$
\mathrm{CM}=(\mathrm{AYM}+\mathrm{AYE}) / \mathrm{AYM} \text {, }
$$

- when the test is during the evening milking (CE - coefficient evening):

$$
\mathrm{CE}=(\mathrm{AYM}+\mathrm{AYE}) / \mathrm{AYE} \text {. }
$$

The predicted individual test day yield on the base of the morning measurement is:

$$
\mathrm{PYM}=\mathrm{YM} \cdot \mathrm{CM} \text {. }
$$

The predicted individual test day yield on the base of the evening measurement is:

$$
\mathrm{PYE}=\mathrm{YE} \cdot \mathrm{CE} \text {. }
$$

The predicted individual TD milk yield was compared to the actual one, YA of the ewe.

Seven traits which characterize the individual ewe milk yield were analyzed: YM (milk yield morning), YE (milk yield evening), YA (milk yield actual), PYM (predicted milk yield morning), PYE (predicted milk yield evening), DM (difference morning), DE (difference evening), where the first 5 were described above and the last two, were the difference of the predicted and actual individual ewe yield by the morning measurement (DM) and the evening measurement (DE):

$$
\mathrm{DM}=\mathrm{PYM}-\mathrm{YA} \text { and DE}=\mathrm{PYE}-\mathrm{YA} \text {. }
$$

The traits were analyzed for the influence of four factors: number of lambs born (NLB), month and year of test (MYtest), period of test (SMP) during the suckling period (1) or in the milking only period (2) and level of actual production (LYA) within flock month of test, where ewes were separated in three classes - high (1), medium (2) and low (3) productivity. Approximately one third of each month/year of test records were set to each level.

Edition of the original data. Only nonzero records were used in the study. In case when morning or evening measurement was missing the whole individual record was omitted. These were $17 \%$ of the individual data, which left in the study 1760 ewe records. The age of the ewes were from the 1-st to 7-th lactation.

The statistical analysis was made by a 4-way fixed ANOVA without interactions.

\section{RESULTS AND DISCUSSION}

\section{Average actual and predicted TD milk yield}

Average values for the studied traits (Table 1) showed a milk production level that is typical for dairy sheep. Mean daily milk yield constituted about 1 liter for 290 days lactation period. The minimum daily yield was 0.2 (li) and the maximum was 4.0 liters. The morning average was slightly smaller then the evening one, 0.45 vs 0.50 liters.

Table 1

Averages for the studied traits $(N=1760)$

\begin{tabular}{lcccc}
\hline \hline Traits & Min & Max & Average & Std. deviation \\
\hline YM (lit.) & 0.1 & 2.00 & 0.4499 & 0.24366 \\
YE (lit.) & 0.1 & 2.00 & 0.5037 & 0.26241 \\
YA (lit.) & 0.2 & 4.00 & 0.9536 & 0.49169 \\
PYM (lit.) & 0.203 & 4.0989 & 0.9536 & 0.51095 \\
PYE (lit.) & 0.197 & 3.9058 & 0.9535 & 0.49760 \\
DM (lit.) & -1.2591 & 0.7989 & 0.000077 & 0.11513 \\
DM (\%) & -82.8354 & 67.8710 & -0.317865 & 10.1846 \\
DE (lit.) & -0.8344 & 1.0723 & -0.000077 & 0.10651 \\
DE (\%) & -66.9041 & 84.0063 & 0.257628 & 9.3587 \\
\hline \hline
\end{tabular}

YM - actual morning, YE - evening, and YA - daily milk yield, PYM - predicted yield on the base of morning or PYE test evening and DM - difference of the predicted and actual yield on the base of morning or DE measurement - evening, expressed in liters and in $\%$ of the YA.

Certain values of daily milk yield in EastFriesian sheep in Macedonia, which are between the abovementioned, determined by Pacinovski et al. $(2007 \mathrm{a}, \mathrm{b}, \mathrm{c})$, who in three successive trials in this breed, found an average daily milk yield of $1.41,1.83$ and 1.36 liters.

The average predicted yields were almost the same, coincided to the third digit, to the actually measured yield. The SD however in the predicted yields were twice bigger which suggested somewhat higher variation for them. Average differences of the predicted from the actual yield were negligible but again the variation of the differences in actual measurements and in percentage was big enough in order to be analyzed further.

\section{Prediction coefficients of the TD yield}

The prediction coefficients for the studied month/years of test are in Table 2. They showed relatively equal productivity level in the morning and in the evening. As this was found for almost all classes it should be assumed as a breed specific feature. When the mean morning (YM) was lower than the evening (YE), then the morning coeffi- 
cient $\mathrm{CM}$ had higher values then the evening one. Only for several test months in 2006 the morning yield exceeded the evening one, but in both cases the average milk yield during the day were similar.

In the case of this study $\mathrm{CM}$ and $\mathrm{CE}$ coefficients had similar values, varying from 1.7 to 2.3 . For breeds and populations where the level of milk production is almost the same, the prediction with a flock/test day coefficient could be expected to be accurate enough. Possible differences might be due to individual differences in the milking, which normally exist in each population and to some external reasons which are not of biological origin. The analyses in Table 2 were an attempt to reveal the reasons for prediction differences of the individual TD yield in order to propose a better prediction based on a once-a-day individual measurement of the milk yield.

Table 2

Prediction coefficients for the studied month/year of test data (MYtest), on the bases of the actual average milk yield (YA)

\begin{tabular}{|c|c|c|c|c|c|c|}
\hline MYtest & $\mathrm{N}$ & Average YM (1) & Average YE (1) & $\mathrm{CM}$ & $\mathrm{CE}$ & Average YA (l) \\
\hline 12006 & 12 & 0.9042 & 1.0908 & 2.206370 & 1.828933 & 1.9950 \\
\hline 12008 & 88 & 0.4291 & 0.5067 & 2.180844 & 1.846852 & 0.9358 \\
\hline 22006 & 24 & 0.8246 & 0.9533 & 2.156076 & 1.864995 & 1.7779 \\
\hline 22008 & 71 & 0.4204 & 0.4910 & 2.167935 & 1.856212 & 0.9114 \\
\hline 32006 & 67 & 0.8040 & 0.9176 & 2.141294 & 1.876199 & 1.7216 \\
\hline 32008 & 90 & 0.4031 & 0.4698 & 2.165468 & 1.858025 & 0.8729 \\
\hline 42005 & 25 & 1.0520 & 1.1040 & 2.049430 & 1.952899 & 2.1560 \\
\hline 42006 & 75 & 0.7209 & 0.7768 & 2.077542 & 1.928038 & 1.4977 \\
\hline 42008 & 92 & 0.3812 & 0.4476 & 2.174187 & 1.851653 & 0.8288 \\
\hline 52005 & 40 & 0.5912 & 0.7250 & 2.226319 & 1.815448 & 1.3162 \\
\hline 52006 & 83 & 0.6617 & 0.6335 & 1.957382 & 2.044515 & 1.2952 \\
\hline 52008 & 92 & 0.3689 & 0.4251 & 2.152345 & 1.867796 & 0.7940 \\
\hline 62005 & 53 & 0.6462 & 0.8019 & 2.240947 & 1.805836 & 1.4481 \\
\hline 62006 & 85 & 0.6304 & 0.6262 & 1.993338 & 2.006707 & 1.2566 \\
\hline 62008 & 92 & 0.3489 & 0.4051 & 2.161078 & 1.861269 & 0.7540 \\
\hline 72005 & 53 & 0.7283 & 0.8566 & 2.176164 & 1.850222 & 1.5849 \\
\hline 72006 & 85 & 0.4434 & 0.4339 & 1.978575 & 2.021894 & 0.8773 \\
\hline 72008 & 92 & 0.3289 & 0.3851 & 2.170873 & 1.854064 & 0.7140 \\
\hline 82005 & 53 & 0.4232 & 0.5651 & 2.335302 & 1.748894 & 0.9883 \\
\hline 82006 & 85 & 0.3680 & 0.3534 & 1.960326 & 2.041313 & 0.7214 \\
\hline 82008 & 92 & 0.3089 & 0.3651 & 2.181936 & 1.846070 & 0.6740 \\
\hline 92005 & 53 & 0.2745 & 0.3698 & 2.347177 & 1.742293 & 0.6443 \\
\hline 92006 & 85 & 0.2389 & 0.2726 & 2.141063 & 1.876376 & 0.5115 \\
\hline 92008 & 91 & 0.2145 & 0.2176 & 2.014452 & 1.985754 & 0.4321 \\
\hline 102008 & 82 & 0.1588 & 0.1629 & 2.025819 & 1.974831 & 0.3217 \\
\hline Total & 1760 & 0.4499 & 0.5037 & / & 1 & 0.9536 \\
\hline
\end{tabular}

\section{Significance of the factors on the actual and predicted TD yield}

The summary of the F-test after the 4-way ANOVA (Table 3) showed that the number of lambs born (NLB) influenced significantly all the traits, the actual, the predicted yields and the difference between them.
Month/year of test (MYtest) influenced only the actual and predicted milk yield, but not the difference between them.

The period of test (SMP), e.g. the test during the suckling period or the milking only period influenced only the actual morning milk yield, predicted daily TD yield and the differences, DM and DE. 
The level of actual milk yield production (LYA) influenced significantly the actual, the predicted milk yield and the differences between them.

Similar results about the influence of these factors on daily milk production at Awassi and
East-Friesian sheep in Macedonia obtained Dimov et al. (2005) and Djabirski et al. (2006).

The estimates of the averages of these four factors are presented in the next part of this study, where their comparisons give a possibility to reveal the differences and possible causes.

Table 3

\section{Significance (P-value) of the factors (number of lambs born, month/year of test, period of test before/after weaning and level of actual daily milk production) on the actual, predicted TD milk yield and the difference between them}

\begin{tabular}{lcccc}
\hline \hline \multirow{2}{*}{ Traits } & \multicolumn{3}{c}{ Factors } \\
\cline { 2 - 5 } & NLB & MY-test & SMP & LYA \\
\hline Df & 2 & 24 & 1 & 2 \\
Milk yield morning, YM & $0.000^{* * *}$ & $0.000^{* * *}$ & $0.013^{* *}$ & $0.000^{* * *}$ \\
Milk yield evening, YE & $0.000^{* * *}$ & $0.000^{* * *}$ & $0.286^{\mathrm{ns}}$ & $0.000^{* * *}$ \\
Milk yield total, YA & $0.000^{* * *}$ & $0.000^{* * *}$ & $0.429^{\mathrm{ns}}$ & $0.000^{* * *}$ \\
Predicted TD yield by morning milking, PYM & $0.000^{* * *}$ & $0.000^{* * *}$ & $0.017^{* *}$ & $0.000^{* * *}$ \\
Predicted TD yield by evening milking, PYE & $0.000^{* * *}$ & $0.000^{* * *}$ & $0.261^{\mathrm{ns}}$ & $0.000^{* * *}$ \\
Difference TD predicted yield in the morning - actual TD yield, DM & $0.000^{* * *}$ & $1.000^{\mathrm{ns}}$ & $0.003^{* *}$ & $0.000^{* * *}$ \\
Difference TD predicted yield in the evening - actual TD yield, DE & $0.000^{* * *}$ & $0.999^{\mathrm{ns}}$ & $0.001^{* * *}$ & $0.000^{* * *}$ \\
\hline \hline
\end{tabular}

ns - non significant, * $-\mathrm{P}<0.05, * *-\mathrm{P}<0.01, * * *-\mathrm{P}<0.001$

\section{Number of lambs born (NLB)}

Distribution of the TD milk yield records in the three NLB classes (Table 4) showed 54\% single born, $42 \%$ twins and the rest were triples. For all three classes (ewes with high, medium and low milk production) the measured YM (milk yield morning) and YE (milk yield evening) the general tendency were followed for higher evening productivity, which was somewhat higher in the ewes with multiple lambs.

Prediction by the morning measurement (PYM), for the ewes with singles was slightly behind the actual TD yield, YA and the difference (DM) was slightly positive, e.g. the predicted TD yield based on its morning measurement was overestimated. PYM for ewes with more than one lamb underestimated the YA which reflected in negative difference in the DM prediction. The difference was 0.024 liters for ewes with twins and 0.015 liters for the ewes with triples. Prediction by the evening measurement (PYE), for single born lambs very slightly overestimated the YA and overestimated the PYE for the ewes with 2 and more lambs.

Results showed that the predicted TD yield depends on the daily period of measurement and the number of lambs per ewe. The difference in prediction of the YA was much more obvious for the multiparous ewes. The PYM was 1-2\% lower the actual milk yield (YA) and PYE was exceeded it with the same $1-2 \%$. Possible reason for this difference could be in partial suckling of the lambs, especially in the morning milking. It is sometimes difficult to separate the lambs from their mothers $12 \mathrm{~h}$ before the test milking and even the efforts are made by all participants in the test procedures some exceptions exist and may influence the results of test, not only for the predicted yield, but of the actual one (YA). The problem however could not be recognized in the day of test, but after accumulation of the next and perhaps of all lactation records of a ewe. How to discover deviations in the morning milk yield and how to treat them in the future is a matter of special study. Among many two possible solutions would be to discard these records or to replace them with the flock/test day average.

Significant impact on of the number of lambs born on the difference between predicted and real milk production at Awassi breed of sheep, was found by Pacinovski et al. (2014). 


\section{Suckling/milking period (SMP)}

Most of the records were made in the milking period only, and about $22 \%$ were performed during the suckling period (Table 4). The actual yield in the evening was slightly higher than that in the morning. The predicted yield based on the morning milking (PYM) and on the evening milking (PYE) were closer to the milk actual yield (YA) for the period after weaning of the lambs. Then the average difference was about $8 \mathrm{ml}$ with overestimation in the morning and underestimation in the evening, which represented about $0.7 \%$ deviation. Much higher was the difference in the prediction during the suckling period. The morning test underestimated the actual milk yield (YA) with $30 \mathrm{ml}$ $(2.7 \%)$.

The effect of the suckling period seams to be important also and the records, especially in the morning milking should be checked before their further utilization for the breeding and selection purposes. This check of the records does not depend on the discussed A4 or AC4 methods of test, however the study revealed relative importance of the test period in the application of the milk yield test procedure.

\section{Test day level of production (LYA)}

As the number of records per group was kept almost constant in each year/test day the levels of estimated means for the actual yield, YM, YE and YA, showed an expected decreasing tendency from group 1 to group 3 (Table 4). The differences in the means of these actual measurements were about 0.15 liters in the morning and in the evening measurement, and about 0.3 liters for the day of test. Predicted yield from the morning measurement (PYM) and from the evening one (PYE) followed the same tendency and differ between them with almost the same level.

\section{Table 4}

Estimates of the means for the actual and predicted TD milk yield-number of lambs born, tests in the suckling or milking periods and TD level of production effects

\begin{tabular}{|c|c|c|c|c|c|c|c|c|}
\hline \multirow{2}{*}{ Factors } & \multirow{2}{*}{$\mathrm{N}$ obser } & \multicolumn{7}{|c|}{ Traits, liters } \\
\hline & & YM & YE & YA & PYM & PYE & DM & $\mathrm{DE}$ \\
\hline \multicolumn{9}{|l|}{ NLB } \\
\hline 1 & 947 & $0.505 \pm 004$ & $0.568 \pm 004$ & $1.073 \pm 007$ & $1.078 \pm 008$ & $1.069 \pm 008$ & $0.005 \pm 005$ & $-0.004 \pm 004$ \\
\hline 2 & 743 & $0.490 \pm 004$ & $0.579 \pm 005$ & $1.069 \pm 007$ & $1.045 \pm 009$ & $1.091 \pm 009$ & $-0.024 \pm 005$ & $0.022 \pm 005$ \\
\hline 3 & 70 & $0.562 \pm 012$ & $0.653 \pm 013$ & $1.214 \pm 021$ & $1.199 \pm 025$ & $1.228 \pm 025$ & $-0.015 \pm 015$ & $0.014 \pm 013$ \\
\hline \multicolumn{9}{|l|}{ SMP } \\
\hline 1 & 387 & $0.506 \pm 009$ & $0.606 \pm 010$ & $1.111 \pm 015$ & $1.081 \pm 019$ & $1.142 \pm 018$ & $-0.030 \pm 011$ & $0.030 \pm 010$ \\
\hline 2 & 1373 & $0.532 \pm 005$ & $0.594 \pm 005$ & $1.126 \pm 009$ & $1.134 \pm 010$ & $1.117 \pm 010$ & $0.008 \pm 006$ & $-0.008 \pm 006$ \\
\hline \multicolumn{9}{|l|}{ LYA } \\
\hline 1 & 576 & $0.664 \pm 006$ & $0.740 \pm 006$ & $1.404 \pm 010$ & $1.414 \pm 012$ & $1.395 \pm 012$ & $0.010 \pm 007$ & $-0.008 \pm 006$ \\
\hline 2 & 608 & $0.507 \pm 006$ & $0.589 \pm 006$ & $1.095 \pm 010$ & $1.083 \pm 013$ & $1.108 \pm 012$ & $-0.013 \pm 007$ & $0.013 \pm 007$ \\
\hline 3 & 576 & $0.385 \pm 006$ & $0.471 \pm 006$ & $0.856 \pm 010$ & $0.826 \pm 012$ & $0.885 \pm 012$ & $-0.031 \pm 007$ & $0.028 \pm 007$ \\
\hline
\end{tabular}

The difference of the predicted and actual yield was positive ( 0.010 liters) for the higher level of production based on the morning milking and almost the same way $(-0.008$ liters $)$ underestimated on the base of the evening data. For the middle production class the predicted yield in the morning (DM) was underestimated with 0.013 liters and for the lower level class with 0.031 liters. Similar differences (DE) but with opposite sign were observed for the prediction based on the evening measurement. Results showed that high yielded ewes were overestimated based on the re- sults of the morning test and underestimated based on the evening test. In general AC4 method with morning individual test would increase the variation in the population while the evening test would decrease the differences in the YA. It coincides with the estimated SD of the predicted yield (Table 1).

The difference in the predicted yield was about $1 \%$ of the actual yield for the high and medium level class and about 3.5\% for the group with the lowest milk yield. It is matter of expert to estimate the compromise between the more accurate 
TD measurement (A4), and its simplification with AC4 method.

According to Ivanova (2014), total milking milk is slightly decreasing with AC method for 120 days. In another research Gievski et al. (2006) obtained from limited number of sheep of Awassi breed in Macedonia that the correlation between the two methods (A4 and AC4) is high, with maximal variations in prediction from 1.9 to 3.4 liters.

\section{Month/year of test effect (MYtest)}

The combined, mainly environmental effect of the day of test is rather complex in its influence on the individual and average flock production level. It might affect the milk yield by the specific for the year and season climatic and nutrition conditions. With the sheep seasonal lambing it overlaps to the stage of lactation and the level of production. Some of the months are in the suckling and others in the milking only period.

Results showed that the morning prediction during the first months (December-February) overestimates with less than $1 \%$ the actual milk yield (YA), then in April the prediction is very good, in the second part of lactation the prediction underestimated the YA (Table 5).

Table 5

Estimates of the means for the actual and predicted TD milk yield, $L$ - month-year of test effect

\begin{tabular}{|c|c|c|c|c|c|c|c|c|}
\hline MYtest & $\mathrm{N}$ & YM & YE & YA & PYM & PYE & DM & $\mathrm{DE}$ \\
\hline 12006 & 12 & $0.936 \pm 028$ & $1.113 \pm 030$ & $2.049 \pm 048$ & $2.061 \pm 058$ & $2.036 \pm 058$ & $0.012 \pm 034$ & $-0.013 \pm 031$ \\
\hline 12008 & 88 & $0.460 \pm 012$ & $0.526 \pm 013$ & $0.986 \pm 020$ & $1.000 \pm 025$ & $0.971 \pm 024$ & $0.014 \pm 014$ & $-0.015 \pm 013$ \\
\hline 22006 & 24 & $0.858 \pm 020$ & $0.975 \pm 022$ & $1.833 \pm 035$ & $1.847 \pm 042$ & $1.817 \pm 042$ & $0.015 \pm 024$ & $-0.015 \pm 023$ \\
\hline 22008 & 71 & $0.452 \pm 013$ & $0.511 \pm 014$ & $0.962 \pm 022$ & $0.976 \pm 027$ & $0.948 \pm 026$ & $0.014 \pm 015$ & $-0.015 \pm 014$ \\
\hline 32006 & 67 & $0.832 \pm 012$ & $0.938 \pm 013$ & $1.770 \pm 021$ & $1.780 \pm 026$ & $1.759 \pm 026$ & $0.010 \pm 015$ & $-0.011 \pm 014$ \\
\hline 32008 & 90 & $0.409 \pm 012$ & $0.501 \pm 013$ & $0.910 \pm 021$ & $0.887 \pm 025$ & $0.933 \pm 025$ & $-0.023 \pm 015$ & $0.023 \pm 013$ \\
\hline 42005 & 25 & $1.061 \pm 019$ & $1.110 \pm 020$ & $2.171 \pm 033$ & $2.175 \pm 039$ & $2.168 \pm 039$ & $0.004 \pm 023$ & $-0.003 \pm 021$ \\
\hline 42006 & 75 & $0.745 \pm 012$ & $0.799 \pm 012$ & $1.544 \pm 020$ & $1.549 \pm 024$ & $1.539 \pm 024$ & $0.005 \pm 014$ & $-0.005 \pm 013$ \\
\hline 42008 & 92 & $0.387 \pm 012$ & $0.479 \pm 013$ & $0.867 \pm 021$ & $0.844 \pm 025$ & $0.889 \pm 025$ & $-0.023 \pm 014$ & $0.023 \pm 013$ \\
\hline 52005 & 40 & $0.602 \pm 015$ & $0.741 \pm 016$ & $1.342 \pm 026$ & $1.339 \pm 031$ & $1.346 \pm 031$ & $-0.004 \pm 018$ & $0.003 \pm 017$ \\
\hline 52006 & 83 & $0.673 \pm 012$ & $0.662 \pm 012$ & $1.336 \pm 020$ & $1.321 \pm 024$ & $1.350 \pm 024$ & $-0.015 \pm 014$ & $0.014 \pm 013$ \\
\hline 52008 & 92 & $0.375 \pm 012$ & $0.457 \pm 013$ & $0.832 \pm 021$ & $0.809 \pm 025$ & $0.854 \pm 025$ & $-0.023 \pm 014$ & $0.023 \pm 013$ \\
\hline 62005 & 53 & $0.658 \pm 013$ & $0.821 \pm 014$ & $1.479 \pm 023$ & $1.474 \pm 028$ & $1.484 \pm 027$ & $-0.005 \pm 016$ & $0.005 \pm 015$ \\
\hline 62006 & 85 & $0.640 \pm 012$ & $0.656 \pm 013$ & $1.296 \pm 020$ & $1.278 \pm 024$ & $1.313 \pm 024$ & $-0.017 \pm 014$ & $0.017 \pm 013$ \\
\hline 62008 & 92 & $0.355 \pm 012$ & $0.437 \pm 013$ & $0.792 \pm 021$ & $0.769 \pm 025$ & $0.814 \pm 025$ & $-0.023 \pm 014$ & $0.023 \pm 013$ \\
\hline 72005 & 53 & $0.729 \pm 014$ & $0.881 \pm 015$ & $1.610 \pm 025$ & $1.589 \pm 030$ & $1.631 \pm 030$ & $-0.021 \pm 017$ & $0.021 \pm 016$ \\
\hline 72006 & 85 & $0.450 \pm 012$ & $0.465 \pm 013$ & $0.915 \pm 021$ & $0.894 \pm 025$ & $0.936 \pm 025$ & $-0.021 \pm 015$ & $0.021 \pm 014$ \\
\hline 72008 & 92 & $0.335 \pm 012$ & $0.417 \pm 013$ & $0.752 \pm 021$ & $0.729 \pm 025$ & $0.774 \pm 025$ & $-0.023 \pm 014$ & $0.023 \pm 013$ \\
\hline 82005 & 53 & $0.424 \pm 014$ & $0.589 \pm 015$ & $1.013 \pm 025$ & $0.992 \pm 030$ & $1.035 \pm 030$ & $-0.021 \pm 017$ & $0.021 \pm 016$ \\
\hline 82006 & 85 & $0.374 \pm 012$ & $0.385 \pm 013$ & $0.759 \pm 021$ & $0.737 \pm 025$ & $0.781 \pm 025$ & $-0.022 \pm 015$ & $0.022 \pm 014$ \\
\hline 82008 & 92 & $0.315 \pm 012$ & $0.397 \pm 013$ & $0.712 \pm 021$ & $0.689 \pm 025$ & $0.734 \pm 025$ & $-0.023 \pm 014$ & $0.023 \pm 013$ \\
\hline 92005 & 53 & $0.275 \pm 014$ & $0.394 \pm 015$ & $0.669 \pm 025$ & $0.648 \pm 030$ & $0.691 \pm 030$ & $-0.021 \pm 017$ & $0.021 \pm 016$ \\
\hline 92006 & 85 & $0.245 \pm 012$ & $0.304 \pm 013$ & $0.549 \pm 021$ & $0.527 \pm 026$ & $0.571 \pm 025$ & $-0.022 \pm 015$ & $0.022 \pm 014$ \\
\hline 92008 & 91 & $0.220 \pm 012$ & $0.249 \pm 013$ & $0.470 \pm 021$ & $0.447 \pm 025$ & $0.492 \pm 025$ & $-0.023 \pm 014$ & $0.022 \pm 013$ \\
\hline 102008 & 82 & $0.158 \pm 012$ & $0.187 \pm 013$ & $0.345 \pm 021$ & $0.324 \pm 026$ & $0.367 \pm 026$ & $-0.022 \pm 015$ & $0.022 \pm 014$ \\
\hline
\end{tabular}


The evening prediction in contrast led to underestimation of the YA in the first months and in its overestimation in the last months of the years. It is possible that the months after June are influenced by decreasing pasture and dropping down of the daily productivity because of the second lactation stage. The absolute deviations (DM and DE) are higher in the second part of the lactation period, which mean also that the relative error is also higher because of lactation curve.

The results suggest that in case of simplification of the recording method a monthly shift in the measurement should be more appropriate, e.g. the AT4 method. Special studies in that direction are in progress.

\section{CONCLUSION}

Simplification of the milk recording in sheep from A4 to AC4 method with single measurement of the individual milk yield is possible and lead to average underestimation of the actual yield of $0.3 \%$ using morning milking and $0.3 \%$ overestimation with using evening milking.

Ewes with two and three lambs were underestimated with $1-2 \%$ of the actual TD yield with morning based milk recording.

The morning recording of the milk yield in the suckling period led to underestimation of the TD yield with about $3 \%$. The AC4 morning prediction of the TD yield in the milking period is much more accurate.

Ewes with high milk production are overestimated with $1 \%$ with morning milking, while average and ewes with low milk production are underestimated with $1 \%$ and $3 \%$.

The morning prediction (PYM) overestimated the milk yield actual (YA) in the first part of the lactation with about $1 \%$, gave almost accurate prediction in the middle of it and underestimated the YA with about $4 \%$ in the second part of the milking only period.

\section{REFFERENCES}

[1] Dimov G., Pacinovski N., Gievski M.: Preliminary study on the basic factors which influence daily milk production of sheep in the Awassi mediterranean farm. Journal of Mountain Agriculture on the Balkans, Vol. 8 (4): 431447 (2005), Troyan, Bulgaria.

[2] Džabirski V., Pacinovski N., Dimov G., Eftimova Elena, Palaševski B.: Effect of parity, season and test day on daily productivity of East-Friesian ewes in Macedonia. Journal of Mountain Agriculture on the Balkans, Vol. 9 (1) : 54-67 (2006), Troyan, Bulgaria.

[3] Gievski M., Pacinovski N., Dimov G., Palaševski B.: Possibilities for prediction of the test day milk yield based on only one individual test per day in Awassi sheep. 57-th Annual Meeting of the European Association for Animal Production (EAAP), 17-20 September. Antalya, Turkey. Book of abstracts, No 12, p. 90, 2006.

[4] ICAR.: International agreement of recording practices. Guidelines approved by General Assembly held in Niagara Falls, 18 June 2008. Rome, International Committee for Animal Recording, 486 pp., 2009.

[5] ICAR: Procedure proposed for quality assurance regarding AC method. Working group on performance recording of dairy sheep. Cork, May 29, 2012.

[6] Иванова Т.: Млечна продуктивност на овце от синтетичната популация Българска млечна в стадото на ИЖН - Костинброд. Дисертация. Костинброд, 140 с. 2013.

[7] Pacinovski N., Eftimova Elena, Gievski M.: Comparison of milk production ability between Awassi and EastFriesian sheep in Macedonia. III Symposium of Livestock Production with international participation, 12-14 September, Ohrid, Proceedings, pp. 65-72, 2007a (in Macedonian),

[8] Pacinovski N., Dimov G., Eftimova Elena, Palaševski B.: Characterization of the maximum test day yield in the East Friesian ewes in Macedonia. 58-th Annual Meeting of the European Association for Animal Production (EAAP), 26-29 August. Dublin, Ireland. Book of abstracts, No 13, p. 266, $2007 \mathrm{~b}$.

[9] Pacinovski N., Dimov G., Eftimova Elena: Some production traits of the new imported East-Friesian sheep in Macedonia. Biotechnology in Animal Husbandry, Vol. 23 (5-6), Book 1, pp 113-121, 2007c. Belgrade-Zemun, Serbia. Plenary invited paper.

[10] Pacinovski N., Džabirski V., Dimov G., Porču K.: The accuracy of A4 and AC methods for determining lactation in control day in threefold milking of Awassi breed of sheep. $3^{\text {rd }}$ International Conference "State and prospective for development of genetic resources in Animal Breeding", November, 26-27, Borovets, Bulgaria, Book. of Abstracts, pp. 94-95, 2014. 